Herz 2016 · 41:653-654

DOI 10.1007/s00059-016-4504-7

Online publiziert: 14. November 2016

(c) Springer Medizin Verlag 2016

CrossMark

\section{R. Dörr' - B. Maisch²}

'Praxisklinik Herz und Gefäße, Dresden, Deutschland

${ }^{2}$ Philipps Universität Marburg und Herz- und Gefäßzentrum Marburg, Marburg, Deutschland

\title{
Die Suche nach dem Ariadnefaden im Leitlinienlabyrinth
}

Liebe Leser,

das alljährlich jeweils zum Jahresende erscheinende Leitlinien-Heft Nr. 8 der Zeitschrift Herz hat mittlerweile bereits eine langjährige Tradition. Die Intention der Herausgeber ist es, insbesondere die neuesten englischsprachigen Leitlinien der European Society of Cardiology (ESC), die eine Vorreiterrolle für nachfolgende nationale Leitlinien in Europa haben, aber mit einem Umfang von bis $\mathrm{zu} 90$ Seiten im Volltextformat und bis zu 56 Seiten in der Pocketversion nicht immer leicht lesbar sind, im Interesse der Patientenversorgung von deutschsprachigen Koautoren kommentieren und inhaltlich komprimieren zu lassen. Das Ziel dieses Leitlinienheftes soll erneut eine schnellere Verbreitung der wesentlichen Kernbotschaften der ESC-Leitlinien im deutschen Sprachraum sein.

Nach Einschätzungen der internationalen Cochrane Collaboration erfolgt die Alterung medizinischen Wissens heutzutage mit einer Halbwertszeit von weniger als 5 Jahren. Eine Folge dieser hohen wissenschaftlichen Dynamik ist es, dass Leitlinien bereits nach wenigen Jahren veraltet sind und erneut an den Stand der wissenschaftlichen Erkenntnis angepasst werden müssen. Doch nicht nur die hohe zeitliche Dynamik, sondern auch die parallele Existenz verschiedener Leitliniensysteme unterschiedlicher Fachgesellschaften führt zu einem Leitlinienlabyrinth, in dem die Orientierung nicht immer leichtfällt. Für das Fachgebiet der Herz-Kreislauf-Medizin gibt es Leitlinien der ESC, Leitlinien des American College of Cardiology (ACC) und der American Heart Association (AHA), Kommentare der Deutschen Gesellschaft für Kardiologie - Herz- und Kreislaufforschung (DGK) zu den Leitlinien der ESC, Leitlinien der Arbeitsgemeinschaft der Wissenschaftlichen Medizinischen Fachgesellschaften e. V. (AWMF) und Nationale Versorgungsleitlinien (NVL), die gemeinsam von der Bundesärztekammer (BÄK), der Kassenärztlichen Bundesvereinigung (KBV) und der AWMF für Deutschland veröffentlicht werden.

Im Fokus des vorliegenden Leitlinienheftes der Zeitschrift Herz stehen aber vier neue ESC-Leitlinien und ein ESCPositionspapier aus dem Jahr 2016. Die „2016 ESC Guidelines for the diagnosis and treatment of acute and chronic heart failure“ [1], im Volltextformat 85 Seiten, in der Pocketversion 56 Seiten, werden in diesem Schwerpunktheft von Oeing, Tschöpe und Pieske kommentiert. Wesentliche Neuerungen sind die Klassifikation der Herzinsuffizienz (HI) anhand der Auswurffraktion (EF) in drei Untergruppen: 1. HI mit erhaltener Pumpfunktion (HFpEF, LVEF >50\%), 2. HI mit eingeschränkter Pumpfunktion (HFrEF, LVEF <40\%) und 3. einer neuen Entität, HI mit mäßig eingeschränkter (mid-range) Pumpfunktion (HFmrEF, LVEF 40-49\%) und die Einführung von Angiotensin-Rezeptorblocker/Neprilysin-Inhibitoren (ARNIs, Sacubitril/Valsartan) als Klasse-IB-Indikation in die HFrEF-Behandlungsempfehlungen aufgrund der PARADIGMHF-Studiendaten.

Die „2016 European Guidelines on cardiovascular disease prevention in clinical practice“ [2], im Volltextformat
78 Seiten, in der Pocketversion 56 Seiten, werden von Löllgen und Bachl bearbeitet. Im Fokus dieses Beitrags steht der in den 2016-ESC-Leitlinien nur unzureichend berücksichtigte kardiovaskuläre Risikofaktor körperliche Inaktivität, Bewegungsmangel und sitzende Lebensweise.

Die „2016 ESC/EAS Guidelines for the management of Dyslipidaemias“ [3], im Volltextformat 72 Seiten, in der Pocketversion 48 Seiten, werden von Sinning und Landmesser kommentiert. Das LDLCholesterin wird als primäres Behandlungsziel hervorgehoben, was u.a. auch auf die fehlende Wirksamkeit HDL-Cholesterin-anhebender Therapieansätze zurückzuführen ist.

Die „2016 ESC Guidelines for the management of atrial fibrillation developed in collaboration with EACTS“ [4], im Volltextformat 90 Seiten, in der Pocketversion 55 Seiten, werden von Eckardt et al. kommentiert. In der Schlaganfallprävention unterstreicht die Leitlinie den Stellenwert der nicht-Vitamin-K-abhängigen oralen Antikoagulantia (NOAK) gegenüber herkömmlicher Antikoagulation mit Vitamin-K-Antagonisten.

Ein „2016 ESC Position Paper on cancer treatments and cardiovascular toxicity developed under the auspices of the ESC Committee for Practice Guidelines“ [5], im Volltextformat 34 Seiten, in der Pocketversion 39 Seiten, wurde von Hoog und Achenbach bearbeitet. Bedeutsam ist, dass die durch eine Krebstherapie verursachten kardiovaskulären Komplikationen sich akut, aber oft auch erst nach vielen Jahren manifestieren können. 
Zusätzlich wurden wegen der hohen klinischen Relevanz die „2015 ESC Guidelines for the management of infective endocarditis" [6], im Volltext 54 Seiten, in der Pocketversion 36 Seiten, von B. Maisch kommentiert. Sie stützen sich in der Diagnostik zwar unverändert auf die modifizierten DukeKriterien. Bei der Bildgebung sind jetzt neben der klassischen transthorakalen und transösophagealen Echokardiographie auch PET/CT, Kardio-CT und nuklearmedizinische Methoden akzeptierte Nachweismethoden. Neu ist die Empfehlung eines Endokarditisteams im Referenzzentrum für die Diagnostik und Therapie komplexer Patienten. Die Endokarditisprophylaxe bei medizinischen und operativen Eingriffen bleibt auf Hochrisikofälle beschränkt.

Trotz der hohen Dynamik stellen sich bei jedem Leitlinienupdate für die in Klinik und Praxis tätigen Kardiologen immer wieder dieselben drei Schlüsselfragen: 1) Was ist neu? 2) Was ist und bleibt auch besonders wichtig? 3) Sind diese Leitlinienempfehlungen in meinem nationalen Gesundheitssystem umsetzbar? In Entwicklungsländern wird sich bei diesem letzten Punkt die Grundsatzfrage der Finanzierbarkeit der in den ESC-Leitlinien empfohlenen Hochleistungsmedizin ergeben. Entscheidend für die Umsetzbarkeit einer medizinischen Innovation im deutschen System der gesetzlichen Krankenversicherung (GKV) ist die Anerkennung eines Zusatznutzens durch den Gemeinsamen Bundesausschuss (GBA). Die Rechtsgrundlage für den Gemeinsamen Bundesausschuss bildet der $\$ 91$ des Fünften Buches Sozialgesetzbuch (SGB V), eingeführt durch das zum 1.1.2004 in Kraft getretene Gesetz zur Modernisierung der gesetzlichen Krankenversicherung (GMG). Das Gesetz verlangt, dass der diagnostische oder therapeutische Nutzen, die medizinische Notwendigkeit und die Wirtschaftlichkeit von Leistungen nachgewiesen sein müssen, bevor sie Bestandteil des GKVLeistungskataloges werden können. Der GBA erfüllt seine durch den Gesetzgeber übertragenen Aufgaben im Wesentlichen dadurch, dass er Richtlinien beschließt oder bereits bestehende aktualisiert. Diese Richtlinien stehen in der Rangfolge zwar unterhalb von Gesetzen (untergesetzlicher Normencharakter), sind aber dennoch für alle gesetzlich Krankenversicherten und Akteure in der GKV rechtlich bindend. Sie gelten für die ambulante Behandlung bei niedergelassenen Ärzten, Zahnärzten, Therapeuten und Psychotherapeuten sowie bei Behandlungen in Krankenhäusern und Kliniken.

In diesem Umfeld bewegen sich Kardiologen in Klinik und Praxis in einem komplexen Labyrinth bestehend aus medizinischen Leitlinien, von denen aber individuell in begründeten Fällen immer abgewichen werden darf, und gesundheitspolitischen Richtlinien, die rechtlich immer bindend sind und einen untergesetzlichen Normencharakter haben. Die Herausgeber dieses Heftes möchten mit diesem Leitlinienheft erneut versuchen, zumindest für den Bereich der ESC-Leitlinien einen Ariadnefaden in diesem Labyrinth anzubieten. Sie sind sich jedoch der Tatsache bewusst, dass es sich hierbei nur um einen Versuch handeln kann und dass die Rolle des bösen Minotaurus in diesem komplexen Labyrinth nicht analysiert werden konnte. Wir wünschen den Lesern erneut viel Vergnügen bei der Lektüre dieses Leitlinienheftes 8/2016 und einen guten Start in das Neue Jahr 2017 mit Herz.

Ihre

Dr. med. Rolf Dörr

Prof. Dr. med. Bernhard Maisch

\section{Korrespondenzadresse}

\section{Dr. med. R. Dörr}

Praxisklinik Herz und Gefäße

Heinrich-Cotta-Str. 12, 01324 Dresden,

Deutschland

doerr@praxisklinik-dresden.de

Interessenkonflikt. R. Dörr und B. Maisch geben an, dass kein Interessenkonflikt besteht.

\section{Literatur}

1. Ponikowski P, Voors AA, Anker SD et al (2016) 2016 ESC Guidelines for the diagnosis and treatment of acute and chronic heart failure: the Task Force for the diagnosis and treatment of acute and chronic heart failure of the European Society of Cardiology (ESC) Developed with the special contribution of the Heart Failure Association (HFA) of the ESC. Eur Heart J 37(27):2129-2200. doi:10.1093/eurheartj/ ehw128

2. Piepoli MF, Hoes AW, Agewall S et al (2016) 2016 European Guidelines on cardiovascular disease prevention in clinical practice: the Sixth Joint Task Force of the European Society of Cardiology and other Societies on Cardiovascular Disease Prevention in Clinical Practice (constituted by representatives of 10 societies and by invited experts). Developed with the special contribution of the European Association for Cardiovascular Prevention \& Rehabilitation (EACPR). Eur Heart J 37(29):2315-2381. doi:10.1093/eurheartj/ ehw106

3. Catapano AL, Graham I, De Backer G et al (2016) 2016 ESC/EAS Guidelines for the management of dyslipidaemias: the Task Force for the management of dyslipidaemias of the European Society of Cardiology (ESC) and European Atherosclerosis Society (EAS). Developed with the special contribution of the European Assocciation for Cardiovascular Prevention \& Rehabilitation (EACPR). EurHeart J. doi:10.1093/eurheartj/ehw272

4. Kirchhof P, Benussi S, Kotecha D et al (2016) 2016 ESC Guidelines for the management of atrial fibrillation developed in collaboration with EACTS: the Task Force for the management of atrial fibrillation of the European Society of Cardiology (ESC) Developed with the special contribution of the European Heart Rhythm Association (EHRA) of the ESC Endorsed by the European Stroke Organisation (ESO). Eur Heart J. doi:10.1093/ eurheartj/ehw210

5. Zamorano JL, Lancellotti P, Rodriguez Muñoz D et al (2016) 2016 ESC Position Paper on cancer treatments and cardiovascular toxicity developed under the auspices of the ESC Committee for Practice Guidelines: the Task Force for cancer treatments and cardiovascular toxicity of the European Society of Cardiology (ESC). Eur Heart J. doi:10.1093/eurheartj/ehw211

6. Habib G, Lancellotti P, Antunes MJ et al (2015) 2015 ESC Guidelines for the management of infective endocarditis: the Task Force for the management of infective endocarditis of the European Society of Cardiology (ESC). Endorsed by: European Association for Cardio-Thoracic Surgery (EACTS), the European Association of Nuclear Medicine (EANM). Eur Heart J 36(44):3075-3128. doi:10. 1093/eurheartj/ehv319 